\title{
Endoscopic anisakis removal induced anterior cutaneous nerve entrapment syndrome
}

\author{
Takeshi Endo, ${ }^{1}$ Takashi Watari ${ }^{2,3}$
}

'Department of Internal Medicine, Unnan City Hospital, Unnan, Shimane, Japan ${ }^{2}$ General Medicine Center, Shimane University Hospital, Izumo, Shimane, Japan ${ }^{3}$ Master of Healthcare Quality and Safety, Harvard Medical School, Boston, Massachusetts, USA

\section{Correspondence to \\ Dr Takashi Watari; \\ wataritari@gmail.com}

Accepted 5 February 2021

Check for updates

(c) BMJ Publishing Group Limited 2021. No commercial re-use. See rights and permissions. Published by BMJ.

To cite: Endo T, Watari T. BMJ Case Rep 2021;14:e241455. doi:10.1136/bcr-2020241455

\section{DESCRIPTION}

A 66-year-old man without significant medical history presented to our hospital for a routine check-up. He underwent oesophagogastroduodenoscopy (EGD) annually. He reported having eaten mackerel sushi 3 days before the check-up. Transnasal EGD showed anisakid nematodes, which were removed using standard biopsy forceps (figure 1A). The patient did not have any abdominal pain before or during EGD; however, he experienced sudden abdominal pain 15 min after the examination. The pain persisted and was aggravated by movements, walking and moving in bed. Abdominal enhanced CT scan showed no abnormal findings. The pain moved from the lower abdomen to the left side of the umbilicus, and a detailed physical examination revealed a $2 \times 2 \mathrm{~cm}$ tenderness area off the lateral border of the rectus abdominis muscle (figure 1B). Carnett's sign was positive, and the pain exacerbated on slight pinching of the abdominal wall. Sonography revealed tenderness at $1.5 \mathrm{~cm}$ below, at the lateral rectus abdominis muscle border, with no abnormal findings, such as the presence of haematoma. Using sonography, a $1 \%$ xylocaine solution $(5 \mathrm{~mL})$ was injected into the adipose layer and the rectal muscle sheath at a depth of $1 \mathrm{~cm}$ (figure 1C), and the pain disappeared $15 \mathrm{~min}$ later. Anterior cutaneous nerve entrapment syndrome (ACNES) was diagnosed. The patient was discharged from the hospital the next day without having taken any sedative medication. He visited the hospital after 1 week, and at 3 months, we confirmed that there was no abdominal pain recurrence via a telephone call.

ACNES is a nerve ischaemia of the intercostal nerve branches of the thoracic spinal nerve. It occurs because of herniation of the connective adipose tissue surrounding the nerves in the rectus abdominis muscle or the pulling and pushing forces exerted on the same area. ${ }^{1}$ Approximately 5.3\% of the patients who undergo EGD can experience abdominal discomfort within 24 hours of the examination. ${ }^{2} \mathrm{~A}$ patient with a gastric ulcer reportedly developed ACNES 3 days after EGD. ${ }^{3}$ Pneumoperitoneum during EGD causes abdominal wall elongation, which could cause ACNES. Previous studies have reported an association between anisakis and ACNES. However, anisakis causes abdominal pain and gastrointestinal disturbances. ${ }^{4}$ Similar to patients with gastric ulcer who develop ACNES after EGD, ${ }^{3}$ the abdominal wall may have been stimulated by the expansion of the gastric mucosa that was previously damaged by anisakis, and this stimulation may have caused ACNES.

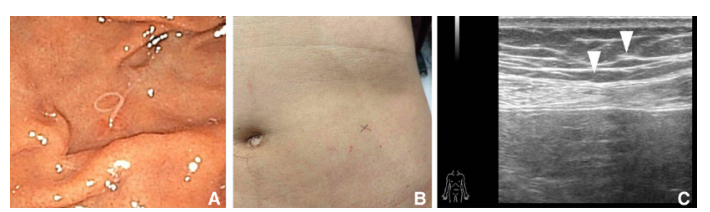

Figure 1 (A) Gastroscopy image of mucosal erythema and anisakis infection. An anisakis infection is inadvertently found during upper gastrointestinal endoscopy. (B) Abdominal tenderness points $(2 \times 2 \mathrm{~cm})$ with Carnett's sign. The pinch sign sensory disturbance is positive at this limited point. (C) Sonography image: the arrowhead points to the local injection site in the subcutaneous adipose layer and the rectal abdominis muscle sheath.

Pinpoint identification of abdominal tenderness is helpful for a definitive ACNES diagnosis. Mol et al indicated that ACNES can be suspected when at least two of the following features are present: sensory disturbance, pinch sign, Carnett's sign and response to a local rectus sheath anaesthetic injection. ${ }^{5}$ Since subjective symptoms may appear beyond a $2 \mathrm{~cm}$ area, detailed palpation is required to detect small tender spots. When a diagnosis of abdominal wall pain can be made because of a positive Carnett's sign, an abdominal CT is usually not necessary; however, a CT scan should still be performed when there are concerns regarding the intra-abdominal aetiology of the pain. ${ }^{6}$ Ultrasonography helps identify masses, abscesses and haematomas in the abdominal wall and deliver accurate and safe local injections into the area. ${ }^{6}$

\section{Learning points}

- Anterior cutaneous nerve entrapment syndrome (ACNES) may develop because of the abdominal wall stress, such as after endoscopic anisakis removal.

- A detailed patient history and careful physical examination can help diagnose ACNES.

- Ultrasonography also helps guide the injection accurately.

Contributors TE and TW cared for the patient and wrote the manuscript together.

Funding The authors have not declared a specific grant for this research from any funding agency in the public, commercial or not-for-profit sectors.

Competing interests None declared.

Patient consent for publication Obtained.

Provenance and peer review Not commissioned; externally peer reviewed. 
Images in...

\section{REFERENCES}

1 Scheltinga MR, Roumen RM. Anterior cutaneous nerve entrapment syndrome (ACNES). Hernia 2018;22:507-16.

2 Zubarik R, Eisen G, Mastropietro C, et al. Prospective analysis of complications 30 days after outpatient upper endoscopy. Am J Gastroenterol 1999;94:1539-45.

3 Okamoto T, Fukuda K. Anterior cutaneous nerve entrapment syndrome occurring after endoscopy. Case Rep Gastroenterol 2020;14:377-82.
4 Shimamura Y, Muwanwella N, Chandran S, et al. Common symptoms from an uncommon infection: gastrointestinal anisakiasis. Can J Gastroenterol Hepatol 2016;2016:1-7.

5 Mol FMU, Maatman RC, De Joode LEGH, et al. Characteristics of 1116 consecutive patients diagnosed with anterior cutaneous nerve entrapment syndrome (ACNES). Ann Surg 2021:273:373-8.

6 Shian B, Larson ST. Abdominal wall pain: clinical evaluation, differential diagnosis, and treatment. Am Fam Physician 2018;98:429-36.

Copyright 2021 BMJ Publishing Group. All rights reserved. For permission to reuse any of this content visit https://www.bmj.com/company/products-services/rights-and-licensing/permissions/

BMJ Case Report Fellows may re-use this article for personal use and teaching without any further permission.

Become a Fellow of BMJ Case Reports today and you can:

- Submit as many cases as you like

- Enjoy fast sympathetic peer review and rapid publication of accepted articles

- Access all the published articles

- Re-use any of the published material for personal use and teaching without further permission

Customer Service

If you have any further queries about your subscription, please contact our customer services team on +44 (0) 2071111105 or via email at support@bmj.com.

Visit casereports.bmj.com for more articles like this and to become a Fellow 